\title{
Moodle-Based Learning Model for Paragraph Writing Class
}

\author{
Mega Wulandari \\ Sanata Dharma University \\ megawuland@gmail.com
}

\begin{abstract}
Today's language classroom is vastly different from that of the twentieth century. The trends in language learning are moving forward in a way as to empower language learners to interact with others. Time and place boundaries are transcended by internet-based media to facilitate the interaction they are eager to make. Language teachers must now be able to utilize internet for language learning, especially in writing class because most learners assume that writing skill is the hardest part of language to learn, which require learners to practice intensively in order to gain mastery. Moodle (Modular, Object-Oriented, Dynamic, and Learning Environment) is one of many internet-based media through which teachers can work with students, whether in distance mode or as a supplement to face-to-face teaching. There are four basic things teachers and students can do with Moodle, namely: storing, communicating, collaborating, and evaluating. Considering those potentials, this research aimed at developing a Moodle learning model of Paragraph Writing at the university level.

The result of the research was the theoretical model and the iconic Moodle learning model. The theoretical model presents the Moodle features that were selected according to their suitability with the theory of paragraph writing as well as with the CALL principles and Gagne's nine events of instruction. The iconic model was developed by making some revisions based on the results of the expert validation and the user validation. The iconic learning model could be accessed on www.writing2pbi.mdl2.com.
\end{abstract}

Keywords: CALL, Paragraph Writing, Moodle, Learning Media

\section{A. BACKGROUND}

Technology nowadays has grown so advanced that almost every aspect of life is inevitably touched by the advancement of technology, including education. In line with the increasingly rapid technological developments, especially after the Internet was invented in 1993, new innovations in learning are also created which involves the integration of education and technology. A learning which utilizes Internet network is now familiar with Elearning (Hrastinski, 2008). Elearning is arguably one of the most powerful responses to the growing need for education which offers practicality, authenticity, flexibility, and interactivity through Internet, overcoming time and travel constraints of conventional placebased face-to-face education (Warschauer, 1997). Internet can also promote autonomous yet collaborative learning. Young, et al (1995), for example, predicts that the Internet will not isolate students, but will enhance learning. He writes: One of the most important educational experiences is collaboration. In some of the world's most creative classrooms, computers and communications networks are already beginning to change the conventional relationships among students 
themselves, and between students and teachers, by facilitating collaborative learning (p. 200). Warschauer, et.al. (2000) mention five main reasons to use the Internet for English teaching. Taken together, these reasons help bring English teaching ALIVE (Authenticity, Literacy, Interaction, Vitality, and Empowerment).

In the era of autonomous yet collaborative learning that has been carried out hastily nowadays, especially in higher education, students are expected to be able to rely much on themselves as well as to assist one another in their learning. While teachers should find a way to accommodate meaningful learning in order to produce more successful learners, students should seek another means of studying outside the classroom so as to eventually be more active and autonomous learning. It complies with theory of constructivism proposed by Vygotsky. Constructivism is the idea that a learner is an active learner who constructs a personal base of knowledge and understanding (Vygostsky, 1999). E-Learning in Constructivism context will be: set of manageable, content-rich, knowledgesharing and collaborative tools. One of the tools which meets those requirements is Moodle, which stands for Modular Object Oriented Dynamic Learning Environment. Moodle, a free and open-source system, is emerging as a more and more popular option to teachers with novice computer background. Although Moodle is not considered as the newest internetbased tool, its ability to enable learners to enter a virtual classroom to access learning materials with low budget yet rich in contents is still recognized. What makes Moodle so interesting are the useful features that can facilitate learners to share links, send personal message and publish their work in a forum to be read by others. The product specification is explained through four basic things teachers and students can do with Moodle, namely storing, communicating, collaborating and evaluating.

The next issue is related to the language learning. The prevailing language for communication on the internet is English. This may be a result of the Internet origin's, as well as English's role as the lingua franca (Castells, 2007). As far as language is concerned, writing in particular has emerged to be the most important skill in day-to-day life. Writing skill plays an important role in the globalization era since the transfer of information and knowledge is done by sharing of pieces of writing. Since writing is a productive skill, it requires the students to practice a lot to attain mastery. Paragraph Writing is one of the obligatory subjects offered in the second semester by English Language Education Study Program (ELESP) of Sanata Dharma University. Paragraph Writing gives students theories and practices on how to write good paragraphs. Students will be introduced to the concept of a good paragraph which includes writing good topic sentence, supporting sentences, and concluding sentence. Students also need to consider other aspects, i.e. concept of unity and cohesion. Frequently, due to large classes, teachers and individual students often have insufficient opportunities to communicate in the classroom to enhance their writing. To address that issue, Moodle with its great potential to cross those boundaries can be a suitable tool to overcome those problems. 


\section{B. METHODOLOGY}

The research method employed was Education Research and Development (R \& D) method. Borg and Gall (1983: 772) stated that "educational research and development (R\&D) is a process used to develop and validate educational products". Moreover, the goal of R \& D was to take the research knowledge and incorporate it into a product that could be used in school (Borg and Gall, 1983:771). It also complies with the ADDIE Instructional Design Model which underwent the following process: Analysis-DesignDevelopment-Implementation-

Evaluation. Therefore, this research used ADDIE Instructional Design Model as framework.

Firstly, in the analysis phase, the learning problems and learner characteristics are identified. Analysis also considers the audience's needs, lacks and wants. Secondly, design phase was executed by deciding learning objectives and lesson planning. After the general objectives had been formulated, the next step was choosing teaching activities and features selection in Moodle. Afterwards, the implementation of the Moodle Learning model in paragraph writing was conducted to provide experience of the newly developed model. Finally, in order to obtain relevant and appropriate materials and learning strategy, the designed learning model needed to be evaluated to ensure the validity. This phase consists of formative and summative evaluation. Formative evaluation was done by asking feedback from a number of experts in Paragraph Writing and ComputerAssisted Language Learning in order to validate the learning model. The researcher chose four lecturers of the English Language Education Study Program with distinct areas of expertise to evaluate the product based on their area of expertise. Therefore the evaluation was called "expert validation". On the other hand, the summative evaluation was conducted to gain feedback from the students. They were expected to evaluate the learning model through their response towards the statements and questions presented in the questionnaires and interview. Therefore, this phase was called "user validation". The five steps ADDIE's design model proposed can be seen in the following figure:

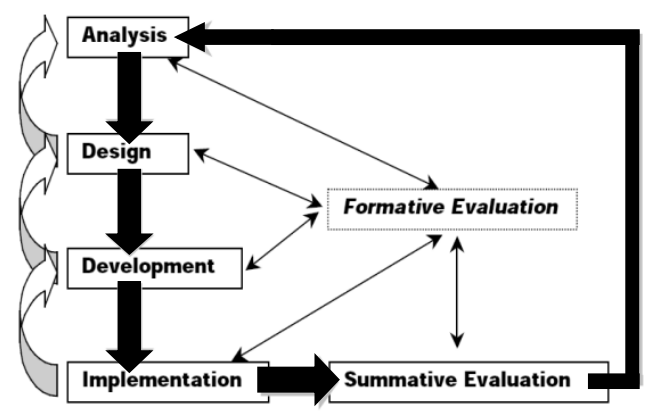

Figure 1 : ADDIE Model (Braxton, Bronico, Looms, 2000)

\section{DISCUSSION}

\section{Analysis Phase}

The analysis phase was conducted to collect information about the need in Paragraph Writing class by interviewing the Paragraph Writing lecturer, distributing questionnaires to the targeted users and analyzing existing e-learning sites to be able to develop an appropriate Moodle learning model for the students.

\section{a. Interview with Paragraph Writing Lecturer}

To begin with, an interview with a lecturer of Paragraph Writing was conducted to collect the data. The data include students' proficiency, the applied teaching strategies, students' characteristics and teaching media. In the interview, the lecturer implied 
that the students' language proficiency, particularly their vocabulary mastery and punctuation, was quite low. The lecturer has attempted to assign students to do peer reviewing or do consultation with the lecturer before submitting their final draft. However, because of the large classes, the lecturer and individual students often have insufficient opportunities to communicate in the classroom and communication outside the class may not occur because a lack of suitable office hour, busy schedules, or simply shyness on the part of the students. The lecturer thinks that the student might need a media which facilitates them to have such interaction outside the classroom. In addition, students often made mistakes on the grammar use. In-depth explanation of the grammar use was needed to overcome this problem. The lecturer usually went over the common errors to be discussed in class after he finished correcting all the submitted compositions. The lecturer admitted that it usually took more than one week to finish the correction. Another finding of this research was the fact that occasionally students could hardly decide the topic sentence of the compositions. Topic sentence plays a role as a determiner of what a composition is about. Students were confused in formulating the opening and closing sentences, how to produce acceptable good sentence for a particular kind of composition. To overcome this problem, the lecturer managed students to form a group, then to have a group discussion. This way, students had possibility to collaborate with other students in developing their ideas.

The lecturer still utilized traditional face to face media in his classes, such as textbooks, additional grammar exercises, and sometimes pictures. Once the lecturer using made an attempt to utilize Blogs and Emails in supporting students' writing process, but the lecturer found difficulties in organizing student's blogs and creating links to student's personal blogs. To connect the lecturer with students' blogs, he should learn HTML coding which he found overwhelming and thus he thought it's very difficult for him to evaluate student's compositions. Furthermore, using email for writing was another intricate thing. This time, the students only make use of emails for sending or submitting tasks which had not finished while the teaching/learning process were conducted at classroom. The emails sent by students were often mixed up with the lecturer's personal emails. Afterwards, he stopped using blogs and emails since it was considered troublesome.

In conclusion, the lecturer expected an instructional material design which maximizes function of Internet as one of the facilities provided by the University. The lecturer needs a media whose ability to provide students with interactive features, provide students with feedback in a short period of time, provide students with unlimited resources, facilitate them to communicate to each other in finishing tasks, and a media which relatively easy to access and simple to navigate.

\section{b. Analyzing the existing e-learning websites}

In order to analyze and investigate the needs of good educational websites characteristics, the researcher reviewed several English Writing websites, e.g. BBC BLAST

(http://www.bbc.co.uk/blast/writing 
/), $\quad$ English Biz

(http://www.englishbiz. co.uk/), Just a Bit: Writing in Small Chunks! (http://edtech2.boisestate.edu/croni nv/ 502/Syllabus_Overview.html), Tefl.net (http://www.tefl.net/), Writing Prompts (http://writingprompts.tumblr.com/) Grammar Girl (http://grammar.quickanddirtytips.co $\mathrm{m} / \mathrm{J}$. The result of this part was the ideal needs response of a Moodle Learning Model for Paragraph Writing.

Since the Moodle learning model would be used online and accessed by means of computer, the learning model would exceptionally have interesting visual design and effective presentation nature. The product combined pictures and color in an ideal amount of highlight relationships and aid learning without being distraction. It complies with the CALL Principle which states that the students will be highly motivated to access a website with interesting visual design.

The learning model broke down the lessons into an ideal number of small frames that allow the students to make choices and apply the principle of effective paragraph writing. The learning model also employed and presented affable font efficiently for its learning texts as well as instruction to allow longer learning endurance and so that they do not clutter the screen and discourage students. These needs responses are ideal because they answered directly to the subject and students needs as well as promoting the use of effective, efficient and attractive principles for further development.

\section{c. An interview with targeted students}

An interview with several first year students also conducted to gain information about their expectation toward the learning model. When they were asked about their expectations of an ideal e-learning for paragraph writing class, most participants expressed that they fancied a class which: (a) provided numerous interactive practices for evaluating their writing skill, (b) had systematic, relevant, and interesting learning materials in form of multimedia content, (c) provided online dictionary, (d) provided downloadable and printable materials, so that they can learn those at home, and (e) is easily navigated.

\section{Design Phase}

After obtaining the necessary data, the researcher then developed the framework of the materials to be designed, which consist of the general objective and competence standard of the materials, the learning topics, the learning indicators, and the organization of the subject content. The framework was formed based on the result of investigating the Paragraph Writing Syllabus (KPE 154) and the available literature on Writing.

From the syllabus the researcher noted that the general purpose of Paragraph Writing lessons is giving students opportunities to practice their writing skills to produce a good paragraph. During the course, students will be introduced to the concept of a good paragraph which covers topic sentence, supporting sentences, and concluding sentence. Students also need to consider other aspects, i.e. concept of unity and cohesion. The Moodle learning model then is designed to accommodate that objective. The goal of the Moodle learning model is to provide students with a practical and efficient approach to learning skills, strategies and knowledge that are necessary for succeeding in content coursework. 
Another goal of the learning model is to provide opportunities for students to explore their opinions, discuss their ideas, and share their experiences through written communication.

Having stated the general objective, the researcher then determined how to measure whether or not the competences have been mastered by specifying the learning indicators. Learning indicators define the performance students should be able to demonstrate in order to be categorized as having achieved the competences standard. Indicators can also be used to construct tests for measuring students' progress as well as the guidelines for selecting tasks and learning materials. The learning indicators for each topic are presented in Table 1.

\section{Table 1. Title and Learning Objectives}

\begin{tabular}{|c|c|c|}
\hline Unit & Title & Learning Objectives \\
\hline 1. & $\begin{array}{l}\text { Paragraph } \\
\text { Organization }\end{array}$ & $\begin{array}{l}\text { In the end of the course, the students are able to: } \\
\text { - } \text { recognize the elements of a paragraph } \\
\text { - } \text { understand the organization of the paragraph } \\
\text { - } \text { identify the function of each elements of a } \\
\text { paragraph } \\
\text { - } \text { analyzing the model of a paragraph } \\
\text { - create a mindmap to help them determine topics } \\
\text { - } \text { to write } \\
\text { - write an outline }\end{array}$ \\
\hline 2. & Topic Sentence & $\begin{array}{l}\text { In the end of the course, the students are able to } \\
\text { - identify the two parts of the topic sentence, } \\
\text { namely topic and controlling idea } \\
\text { - Figure out the general idea as the topic sentence } \\
\text { for a paragraph } \\
\text { - Write the topic sentence in a complete sentence } \\
\text { using the topic and controlling statement for } \\
\text { provided paragraph. }\end{array}$ \\
\hline 3. & $\begin{array}{l}\text { Supporting } \\
\text { Sentences \& } \\
\text { concluding } \\
\text { sentence }\end{array}$ & $\begin{array}{l}\text { In the end of the course, the students are able to: } \\
\text { - } \quad \text { recognize the characteristics of supporting } \\
\text { - } \text { identence and concluding sentence } \\
\text { sentence to form a paragraph } \\
\text { - } \text { arrange jumbled sentences into a good } \\
\text { paragraph } \\
\text { - } \text { write a paragraph using all the elements learned } \\
\text { and post it in web forum } \\
\text { - } \quad \text { criticize friend's paragraph in term of } \\
\text { organization (elements), grammar, idea, and } \\
\text { vocabulary. } \\
\text { - revise their paragraph based on obtained } \\
\text { feedbacks }\end{array}$ \\
\hline 4. & $\begin{array}{l}\text { Unity and } \\
\text { coherence }\end{array}$ & $\begin{array}{l}\text { In the end of the course, the students are able to: } \\
\text { - recognize the important aspects of a paragraph, } \\
\text { namely unity and coherence } \\
\text { - identify unified or unified paragraph } \\
\text { - identify whether the paragraph is coherent or } \\
\text { not }\end{array}$ \\
\hline
\end{tabular}




\begin{tabular}{|c|c|c|}
\hline Unit & Title & Learning Objectives \\
\hline & & $\begin{array}{l}\text { - write a paragraph using all the elements learned } \\
\text { and post it in web forum } \\
\text { review and criticize friend's paragraph in term } \\
\text { of organization (elements), grammar, idea, } \\
\text { vocabulary, unity and coherence } \\
\text { - revise their paragraph based on obtained } \\
\text { feedbacks }\end{array}$ \\
\hline
\end{tabular}

\begin{tabular}{|c|c|}
\hline $\begin{array}{l}\text { Participants } \\
\text { Reports }\end{array}$ & \\
\hline$\checkmark$ General & $\checkmark$ Course Objectives \\
\hline $\begin{array}{l}\text { Course Outlines } \\
\text { W Syllabus of } \\
\text { Paragraph Writing }\end{array}$ & Paraaranh Writing Course Objectives by Unit: \\
\hline 可 News Forum & (2) \\
\hline $\begin{array}{l}\text { 59. Get to know each } \\
\text { other }\end{array}$ & Unit 1 - The Topic Sentence \\
\hline Unit 1 & Students review the elements of a complete sentence and then identify the topic sentence of \\
\hline $\begin{array}{l}\text { Unit } 2 \\
\text { Unit } 3\end{array}$ & a paragraph and create their own topic sentences. \\
\hline Unit 4 - Unity and & Unit 2 - Supporting Sentences / Details \\
\hline Coherence & Students identify supporting details and write their own supporting details. \\
\hline Dnit 5 - Narrative Text & Unit 3 -Closing/Concluding Sentence \\
\hline $\begin{array}{l}\text { Self-Reflection } \\
\text { Topic } 7\end{array}$ & $\begin{array}{l}\text { Students choose the best closing sentence for a paragraph and then create their own. They } \\
\text { also write a complete paragraph. }\end{array}$ \\
\hline
\end{tabular}

Figure 2: Course Objectives on Moodle

\section{Development Phase}

After the general objective, competence standard and unit have been formulated; the next step was choosing teaching activities. Each unit was broken down into four main sections: Module Zone, Exercise Zone, Forum Zone, and Links Zone. The division of the sections was based on the CALL Principle ALIVE (Authenticity, Literacy, Interaction, Vitality and Empowerment).

The summary of the CALL Principles which served as the underlying theory for choosing the learning activities is presented in table 2 .

Table 2: CALL Principles as the basis of choosing learning activities

\begin{tabular}{|l|l|l|l|}
\hline No. & \multicolumn{1}{|c|}{$\begin{array}{c}\text { CALL } \\
\text { Principles }\end{array}$} & \multicolumn{1}{|c|}{ Learning Activities } & \multicolumn{1}{|c|}{$\begin{array}{c}\text { Name of } \\
\text { Section }\end{array}$} \\
\hline 1 & Authenticity & $\begin{array}{l}\text { Students are able to access examples and } \\
\text { downloadable material. }\end{array}$ & Module Zone \\
\hline 2 & Vitality & $\begin{array}{l}\text { Students are able to access materials, } \\
\text { theories 24 hours a day. }\end{array}$ & Module Zone \\
\hline 3 & Interactivity & $\begin{array}{l}\text { Students are able to publish/share their } \\
\text { paragraphs, provide feedback for their } \\
\text { peers, discuss and consult with both } \\
\text { peers and the lecturer. }\end{array}$ & Forum Zone \\
\hline 4 & Literacy & $\begin{array}{l}\text { Students are able to access pre-selected } \\
\text { links to relevant websites and videos }\end{array}$ & Links Zone \\
\hline 5 & Empowerment & $\begin{array}{l}\text { Students are able to assess their } \\
\text { understanding through some numbers of } \\
\text { exercises. }\end{array}$ & Quiz Zone \\
\hline
\end{tabular}




\section{a. Module Zone}

The first selected feature of Moodle was the resource feature in the form of Page, Label, File, Folder and URL. It was in line with the CALL principle of authenticity and vitality. The internet can inject an element of authenticity and vitality into teaching and motivate students as they communicate in a medium that is flexible, content rich, and connected to their real-life needs (Warschauer, 2000). It is presented in Module Zone section.

In this section, the researcher provided knowledge oriented activities to prepare the students by encouraging them to activate or obtain relevant types of knowledge. This allows learners to proceed to the activities from their own experience which allow the learning to become meaningful to them. This page presents materials, theories and paragraph models that are essential to build students' knowledge about the paragraph's nature. This page also provides downloadable materials in form of PDF or PPT files which they can save for future recalling.
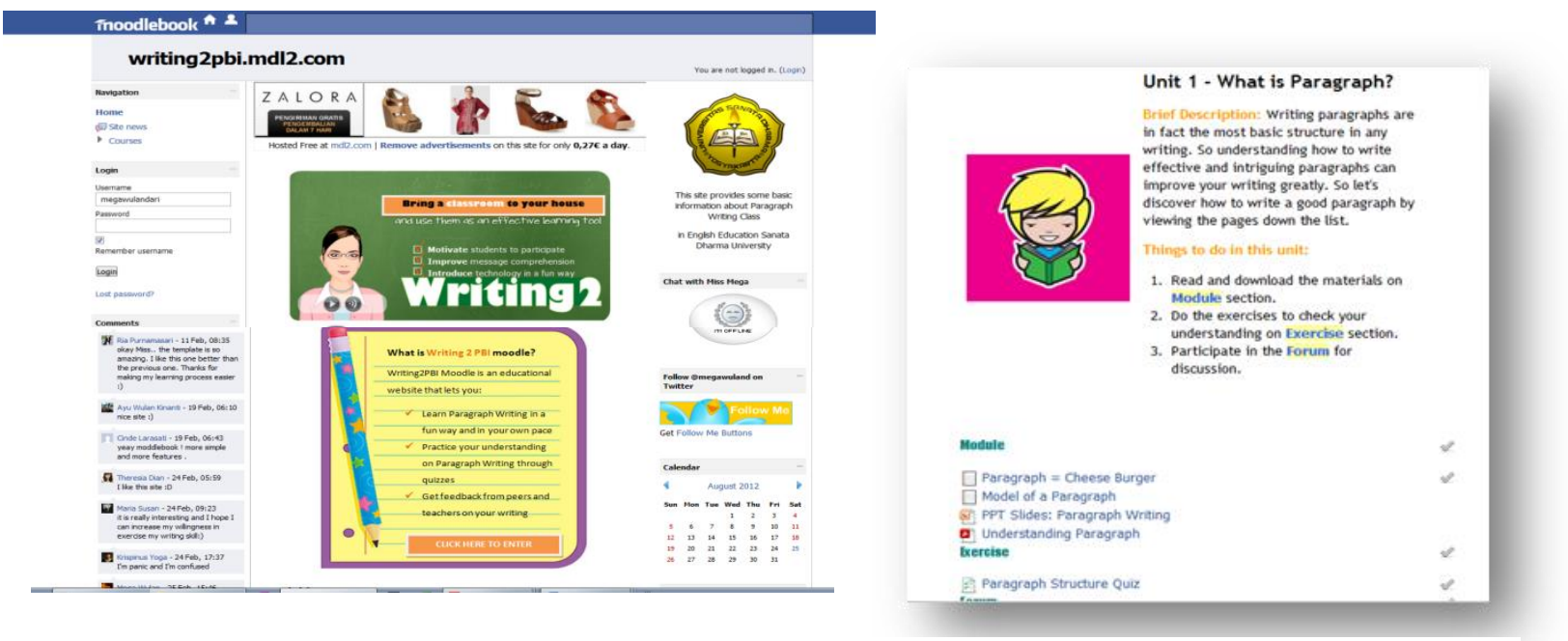

Figure 3: Module Zone

\section{b. Quiz Zone}

The second feature that was selected was quiz feature. This feature was able to support the CALL principle of empowerment. It would enable the students to set their own pace that suits them in learning without disrupting other students. It is presented in Exercise Zone section.

This section aims to measure students' understanding on the discussed topic. This page contains exercises of the learned topic in several kinds of exercises, namely multiple choice, cloze test, gap-filling, picture describing, and arranging sentences. This page also provides obtained score and the lecturer's feedback after students attempted the quiz.

The lecturer can fully control the deadline and timeframes for assignments, quizzes, forums, chats, etc. For example, the lecturers can set deadlines or timeframes when assignments must be completed, whether students can re-submit their 
assignments, and also restrict access has passed.

to learning tasks once the deadline

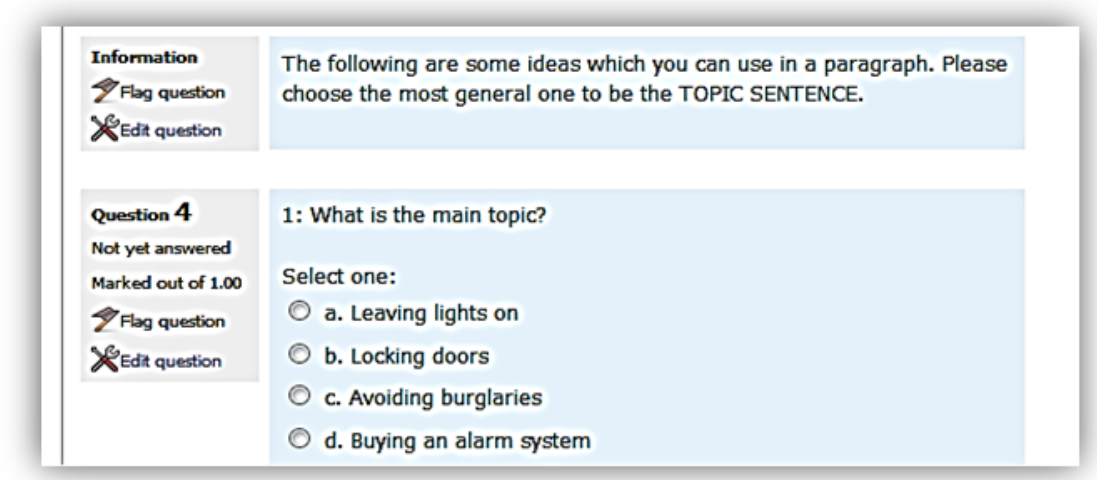

Figure 4: multiple-choice exercise

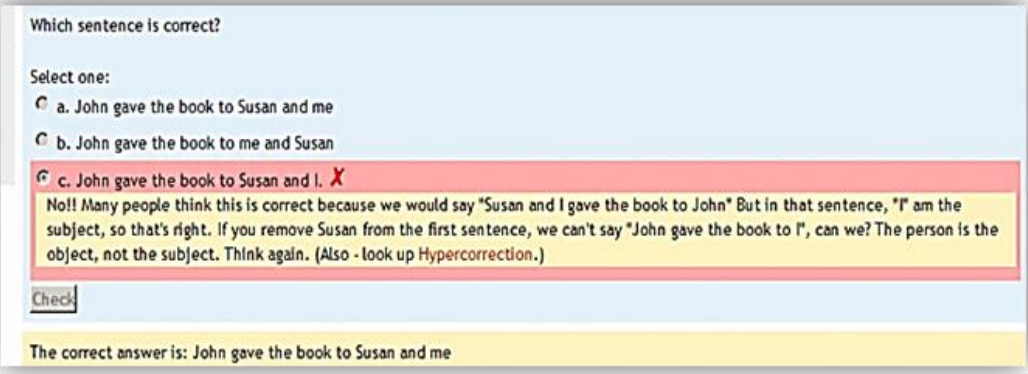

Figure 5: Quiz feedback for incorrect answer
Question 3
Not yet answered
Marked out of 1.00
$\curlyvee$ Flag question
1. Viking is the best way to explore nature closely.
2. My Uncle had a frightening experience as a young man.
$X_{\text {Edit question }}$
3. Text messaging has become popular among teenagers.
4. Effective time management requires four easy steps.
5. Every college student should take a computer course.

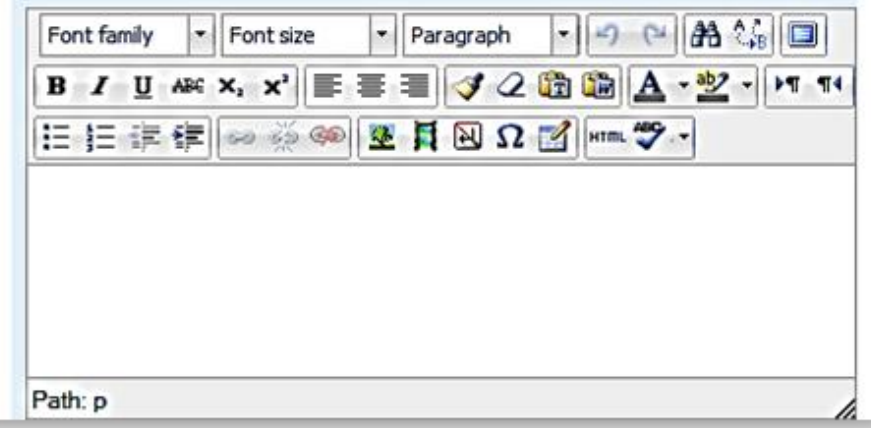

Figure 6: Writing Exercise 


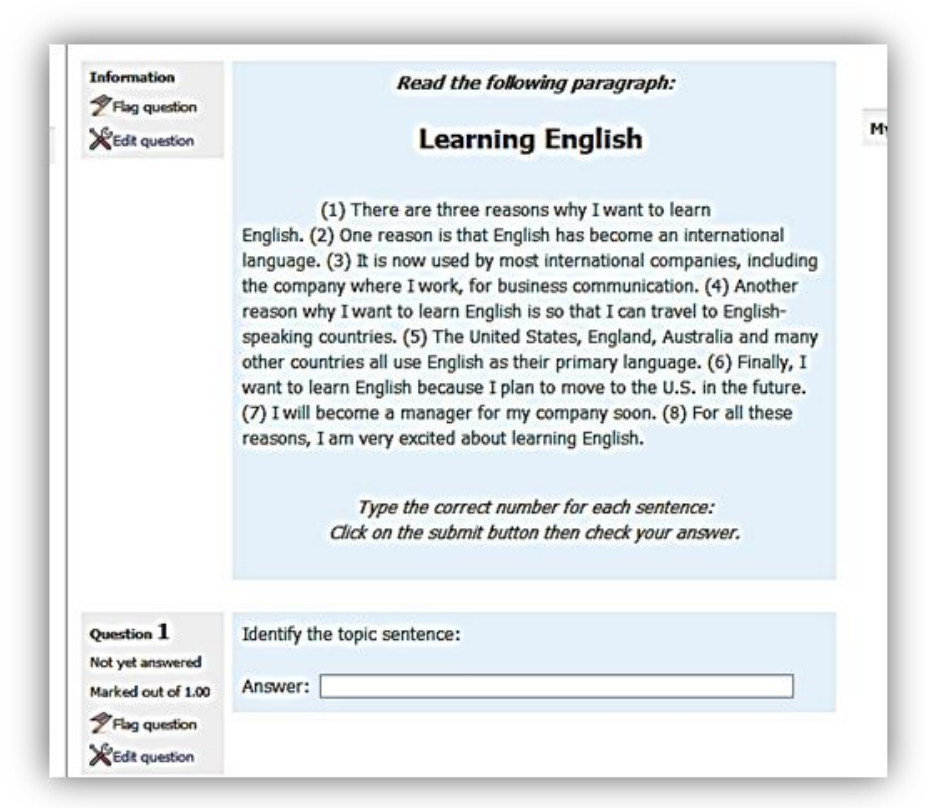

Figure 7: Short Answer Exercise

\section{c. Forum Zone}

The next selected feature from Moodle was forum. This feature served a represent the CALL principle of interaction. According to CALL principle, interaction is the major means of acquiring a language and gaining fluency (Warschauer, 2000). Forum would expand interaction among the students and the teacher. It is presented in Forum Zone section. Chat feature would be also added to serve the principle of interaction. This feature would be connected to the lecturer's mobile phone, thus would give student fast response anytime they meet difficulties.

All the compositions posted are kept in one threaded forum and can be read by the students from any computer connected to the Internet. Each member of the team is assigned to review on the partner's compositions to insure proper structure of the compositions posted in the Moodle. Students were asked to give comment on their friends' paragraphs using thread feature (or reply feature). The comments involve ideas development, organization, grammar, and punctuation. This exercise practices the evaluation skill of the students. The lecturer also contributes to their learning by giving comments as evaluation thus can be the basis to edit and revise their compositions. Moodle can give students an opportunity to edit and revise the compositions or if some new information wants to be added in the previously posted compositions. Finally, the completed and revised compositions are posted in different folder in the Forum for grading. It is aimed to observe how their writing has changed over time. 


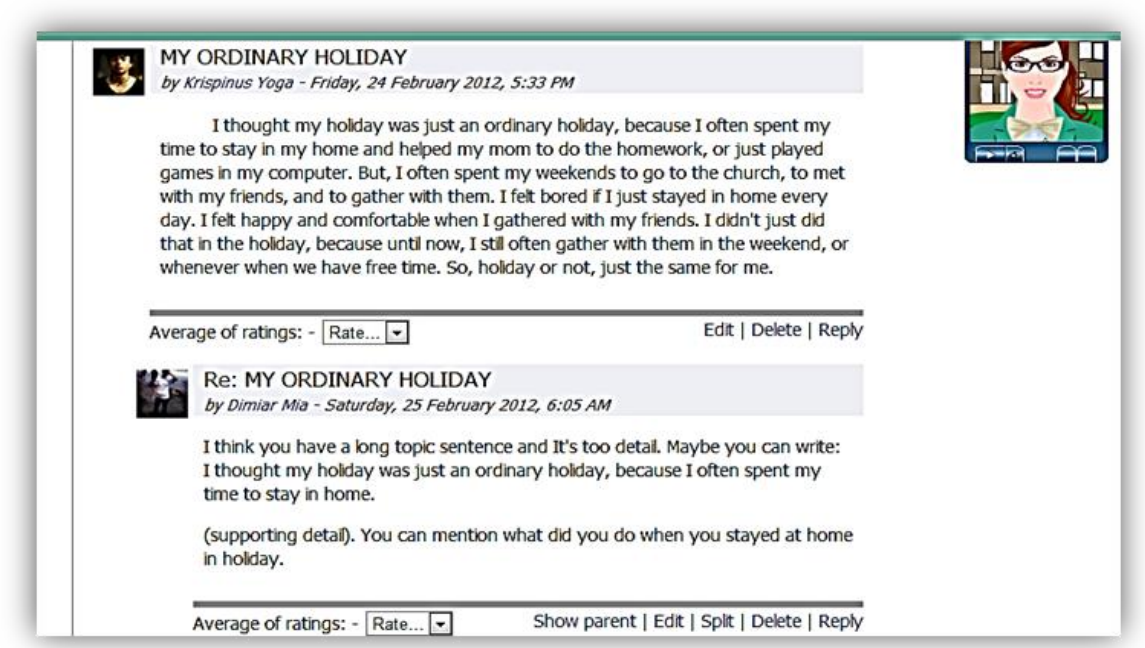

Figure 8: Forum Zone

\section{d. Links Zone}

The ability to read, research, and publish on the internet helps students to master the skills they will need for academic and occupational success. It promotes one of the CALL principles, namely literacy. The main benefit for teachers to use Moodle is that they will be able to provide direct links to relevant websites and resources. Ease of use of Moodle enables regular updating of links and materials Therefore, Links Zone section was created. The Link Zone section serves as an extension of the writing materials. This section lists all the available pre-selected links to relevant websites or videos. Links for website will open in a new window, while for the video; it is already embedded in the website. This additional feature enables students to acquire further content knowledge related to theme of the writing material that may promote further learning.

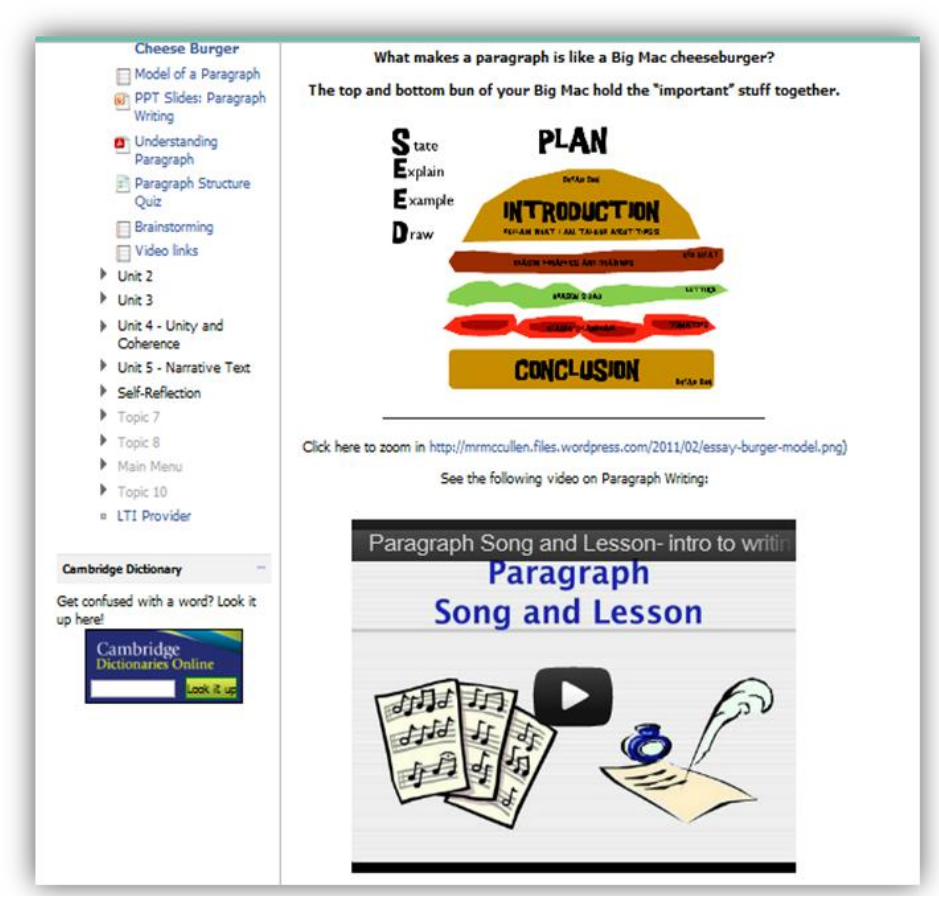

Figure 9: Link Zone and Embedded Video 


\section{Implementation}

After developing the learning model, it was then implemented to the targeted users in five meetings of the Paragraph Writing course, covering the structure of paragraph writing.

Initially, the students were familiarized with the online setting by being informed on how to use Moodle and what they would do in Moodle before the implementation got started which was in Product Dissemination Seminar: Let's Moodle It held by The Graduate Program of English Language Study Sanata Dharma cooperated with SEAMOLEC. It was important to do in order to avoid students from being overwhelmed by any possible technical issues. The guideline that was specially made to ease students in navigating the site was distributed. Therefore, every student could refer to the guideline when having problem in accessing the site. Afterward, the students sign up to enroll at the online course.

After logging in, the students could find detailed instructions provided in each unit section. Students were given the chance to familiarize themselves with Moodle and all the features as well as additional widgets provided in the Moodle. Students were able to review the lesson taught in the classroom through the features provided in the learning model. After that, the students were required to work on the exercises on how to write effective topic sentence, supporting sentences and concluding sentence. Students could also download all materials and power point slides. They were also encouraged to share their writing and gain as much feedback as they could possibly get by posting their writing in the Forum feature.

\section{Evaluation Phase}

The data for this subsection is acquired from the evaluation of the material design by distributing the evaluation questionnaires. There are two parts that will be discussed in this subsection, namely the Descriptive Statistics of Respondents' opinions on the Designed Materials and the Respondents' Comments and Suggestions on the Designed Materials.

After the data were calculated and analyzed, it was found that the results were satisfying. From the respondents' opinions on the designed materials, it was found out that the average point of the central tendency is 4.3 from the scale 5.0. It indicates that the designed materials are good and acceptable for semester 2 students of English Language Education Study Program. However, there was a need to conduct more exploration on the existing part of the design based on the respondents' comments and suggestions. (See appendix 1)

Furthermore, the researcher analyzed comments and suggestions on the designed model by providing the respondents four open-ended questions. From the open-ended questions, the respondents stated that the designed materials had a very interesting layout, varied 
activities, and the materials could develop students' evaluation skill through peer commenting using Moodle. All participants stated that the presentation of the materials was good and attractive. The layout and pictures could support the content of the materials and could persuade students to review the

\begin{tabular}{|c|l|l|l|}
\hline No. & $\begin{array}{c}\text { Parts of the } \\
\text { mistakes }\end{array}$ & \multicolumn{1}{|c|}{ Types of Mistakes } & \multicolumn{1}{|c|}{ Suggestions } \\
\hline 1 & Instruction & Too brief instruction & $\begin{array}{l}\text { Provide clearer instruction to } \\
\text { illustrate the tasks }\end{array}$ \\
\hline 2 & $\begin{array}{l}\text { Learning } \\
\text { indicators }\end{array}$ & $\begin{array}{l}\text { Unclear learning } \\
\text { indicators }\end{array}$ & $\begin{array}{l}\text { The learning indicators should be } \\
\text { measurable and observable }\end{array}$ \\
\hline 3 & Font & Too small font & Font in modules might be enlarged \\
\hline 4 & Advertisement & $\begin{array}{l}\text { Ads may shift away } \\
\text { students' focus and } \\
\text { attention }\end{array}$ & Find a free hosting \\
\hline 5 & Links & Unrelated links & $\begin{array}{l}\text { Specify the links as it will help } \\
\text { students to get more focused }\end{array}$ \\
\hline
\end{tabular}

materials at home. However, there was a need to conduct more exploration on the existing part of the design based on the respondents' comments and suggestions. The respondents' comments and suggestions are presented in table 3 .

\section{Table 3: CALL Principles as the basis of choosing learning activities}

\begin{abstract}
First of all, two participants stated that more detailed instructions should be added in every section of the unit, because the brief instructions were not clear enough to give vivid description on what to do. Second, the learning indicators should be presented on the website because they would serve as the guidelines for the students. The learning indicators should be measurable and observable. The third, the font in modules might be enlarged, such as the title, so the students will easily be attracted. The forth, the ads may shift away students' focus and attention. However, it would be much better to find a free hosting which can host the Moodle without advertisements. The fifth, some links
\end{abstract}

are not in line with learning writing, the participant suggest to specify the links as it will help students to get more focused. The last suggestion is that one expert participant questioned the absence of chat room in the site. However, other expert stated that the use of Yahoo Messenger is sufficient and can be said to be the valuable point of this site.

As respondents suggested that some instructions were not well formulated, the researcher then revised the instructions. In order to ease students to understand so as to encourage them in following the instructed tasks, the researcher made exhaustive yet easilyunderstood instructions which is divided into several parts; what to write, what to post, and how much 
points will be earned. Instructions were then added in every section of the unit and exercises so that the students would know what they were supposed to do without relying too much on the lecturer to give the instructions. By this being made, it opposed the idea that using technology in teaching merely transferring the whole in-class activities into digital version. The idea of E-learning should serve as enabling students to achieve their personal objectives autonomously. The screen shot of the first revision could be seen in figure 10 .

\section{Assignment: Unity and Coherence}

Write: Using this topic sentece: "There are several things that made me dissappointed last semester", develop a full paragraph consisting of several supporting sentences and a conduding paragraph.

Post: Post your paragraph in the forum. Read the work of some of your dassmates and give feedback to at least two of your peers on their supporting sentences and their concluding sentence.

TOTAL POINTS : 100

1. 10 point post it on time (to post your writing, click "Add a new topic" button.

2. 10 point title included (write your title in "Subject" box)

3. 10 point include topic sentence, supporting sentences, and

conduding sentence. Maintain your unity and coeherence using transition.

4. 10 point picture included

5. 20 points on writing quality

6. 20 points commented on 2 other friends' writings (to give comment, click "reply")

7. 20 points on comment quality

Figure 10: Revised version of the instruction

Related to the ads which may shift away students' focus and attention, the researcher found software named AdsBlock which can be used for eliminating the ads from the website hosting the learning model prototype. By installing the software on every computer device used to access the Moodle, no advertisements will appear to distract students' focus.
Furthermore, related to the participants' comment on the provided links, the researcher has eliminated any unrelated links and added some subsidiary links from which the students could obtain some extra references.

In conclusion, by revising and improving the site based on the evaluation, the ideal design of Moodle-based Learning Model for Paragraph Writing is achieved.

\section{CONCLUSIONS}

All features were developed and put under the four sections created to help showing the flow of the course. Those four sections were Module Zone, Exercise Zone, Forum Zone, and Link Zone.

1. Module Zone section required the students to study theory on the topic being learned it also gave the students access to download the learning materials.

2. The Exercise Zone section contained the exercises evaluate the users understanding of the materials given. The exercises offer additional practice in correctly and effectively building sentences and a paragraph.

3. The Forum Zone section serves as a place for students to post and share their writing. This page makes all students' compositions viewable to the whole class members and thus can facilitate the students in comparing and reviewing peers' compositions.

4. Link Zone section allows both students and lecturer to share links to relevant Internet 
resources in form of webpages or videos sorted by topics created by the instructor.

The expert validation questionnaires were distributed to the lecturers of the English Language Education Study Program of Sanata Dharma University and one Moodle user from Monash University, Australia. After the data were analyzed, it was found that the mean from 24 statements was 4,3 out of 5 . The results of the expert validation had implied that theoretical model had been satisfactorily designed and developed, which was then called as the Iconic Model Prototype.

\section{REFERENCES}

Borg, W. R. \&Gall, M. D. (1983).

Educational research: An

introduction. New York: Longman, Inc.

Castells, M. (2007).Rise of the network society. 3 Vols. Vol. 1. Cambridge, MA: Blackwell Publisher.

Harstinski, S. (2008). Asynchronous \& synchronous e-learning. Paper presented at the 28th International
Conference on Information Systems, Montreal, Canada, December 9-12 2007

Vygotskii, L.S. (1978). Mind in society: The development of higher psychological processes. Cambridge, MA: Harvard University Press

Warschauer, M. (1997).Computerassisted language learning: An introduction. Tokyo: Logos

International

Warschauer, M, Shetzer, H., \& Meloni, C. (2000). Internet for English teaching. Virginia: Teachers of English to Speakers of Other Languages, Inc.

Young, Mark R., Bruce R. Klemz, and J. William Murphy. (2003). Enhancing learning outcomes: The effects of instructional technology, learning styles, instructional methods, and student behavior. Journal of Marketing Education 25.2: 130-142.

Appendix 1. The Descriptive Statistics of Expert Validation

\begin{tabular}{|c|c|c|c|c|c|c|c|c|}
\hline \multirow[t]{2}{*}{ No. } & \multirow[t]{2}{*}{ Statements } & \multicolumn{5}{|c|}{$\begin{array}{l}\text { Frequency of points } \\
\text { of agreement }\end{array}$} & \multicolumn{2}{|c|}{$\begin{array}{l}\text { Central } \\
\text { Tendency }\end{array}$} \\
\hline & & $\mathbf{1}$ & 2 & 3 & 4 & 5 & $\mathbf{N}$ & $\mathbf{M}$ \\
\hline 1. & $\begin{array}{l}\text { The learning indicators in the lesson plan } \\
\text { are in line with the basic competences and } \\
\text { standard competences. }\end{array}$ & - & - & - & 1 & 4 & 5 & 4.8 \\
\hline 2. & $\begin{array}{l}\text { The site provides learners with the clear } \\
\text { knowledge of the program objectives. }\end{array}$ & & - & - & 1 & 4 & 5 & 4.8 \\
\hline \multirow[t]{2}{*}{3.} & $\begin{array}{l}\text { Module } \\
\text { a. The explanation of the text type has } \\
\text { been well described in the module. }\end{array}$ & - & - & 1 & 2 & 2 & 5 & 4.2 \\
\hline & $\begin{array}{l}\text { b. Abstract concept of Paragraph Writing } \\
\text { (Principles, Rules, Structure, etc) are } \\
\text { illustrated with concrete and specific }\end{array}$ & - & - & 2 & 2 & 1 & 5 & 3.8 \\
\hline
\end{tabular}




\begin{tabular}{|c|c|c|c|c|c|c|c|c|}
\hline \multirow{2}{*}{ No. } & \multirow{2}{*}{ Statements } & \multicolumn{5}{|c|}{$\begin{array}{l}\text { Frequency of points } \\
\text { of agreement }\end{array}$} & \multicolumn{2}{|c|}{$\begin{array}{l}\text { Central } \\
\text { Tendency }\end{array}$} \\
\hline & & 1 & 2 & 3 & 4 & 5 & $\mathbf{N}$ & M \\
\hline & examples & & & & & & & \\
\hline & $\begin{array}{l}\text { c. The language features are presented in } \\
\text { accordance with the type of text being } \\
\text { discussed. }\end{array}$ & - & - & - & 2 & 3 & 5 & 4.6 \\
\hline & $\begin{array}{l}\text { d. Model text can help students to get an } \\
\text { overview of the types of text being } \\
\text { discussed. }\end{array}$ & - & - & - & 2 & 3 & 5 & 4.6 \\
\hline & $\begin{array}{l}\text { e. Multimedia features (video, animation, } \\
\text { pictures) help learner build their } \\
\text { understanding on the concept of } \\
\text { Paragraph Writing. }\end{array}$ & - & - & - & 2 & 3 & 5 & 4.6 \\
\hline & $\begin{array}{l}\text { f. Downloadable materials in form of PPT } \\
\text { and PDF enrich students knowledge on } \\
\text { the concept of Paragraph Writing }\end{array}$ & - & - & - & 1 & 4 & 5 & 4.8 \\
\hline \multirow[t]{3}{*}{4.} & $\begin{array}{l}\text { Exercise } \\
\text { a. The exercises are able to support the } \\
\text { topic being discussed. }\end{array}$ & - & - & - & 1 & 4 & 5 & 4.8 \\
\hline & $\begin{array}{l}\text { b. The instruction of the exercises are } \\
\text { clear and easy to follow }\end{array}$ & - & - & - & 1 & 4 & 5 & 4.8 \\
\hline & $\begin{array}{l}\text { c. The types of exercises are varied, } \\
\text { thereby obviating the students from } \\
\text { boredom in doing the exercises }\end{array}$ & - & - & - & 3 & 2 & 5 & 4.6 \\
\hline \multirow[t]{4}{*}{5.} & $\begin{array}{l}\text { Forum } \\
\text { a. The forum instructions are clear and } \\
\text { easy to understand. }\end{array}$ & - & - & 1 & 2 & 2 & 5 & 4.2 \\
\hline & $\begin{array}{l}\text { b. The forum activity is able to improve } \\
\text { the learners writing ability. }\end{array}$ & - & - & - & 2 & 3 & 5 & 4.6 \\
\hline & $\begin{array}{l}\text { c. The forum activity is related with the } \\
\text { discussed topic. }\end{array}$ & - & - & - & 1 & 4 & 5 & 4.8 \\
\hline & $\begin{array}{l}\text { d. The forum activity motivates the } \\
\text { learners to do peer reviewing. }\end{array}$ & - & - & - & 2 & 3 & 5 & 4.6 \\
\hline \multirow[t]{2}{*}{6.} & $\begin{array}{l}\text { Drop a Visit } \\
\text { a. The provided links can be accessed } \\
\text { flawlessly. }\end{array}$ & - & - & - & 2 & 3 & 5 & 4.6 \\
\hline & $\begin{array}{l}\text { b. The provided links can can gain } \\
\text { attention and maintain motivation of } \\
\text { the learners while helping learners } \\
\text { understand the materials deeper. }\end{array}$ & - & - & - & - & 5 & 5 & 5 \\
\hline 7. & $\begin{array}{l}\text { The Moodle Learning Model is } \\
\text { appropriate to be implemented for second } \\
\text { semester students of English Education } \\
\text { Study Program }\end{array}$ & - & - & - & 2 & 3 & 5 & 4.6 \\
\hline 8. & $\begin{array}{l}\text { The Moodle Learning Model provides } \\
\text { learners with frequent and varied learning } \\
\text { activities that increase learning success. }\end{array}$ & - & - & - & 1 & 3 & 5 & 4.8 \\
\hline 9. & $\begin{array}{l}\text { The web provides supporting tools } \\
\text { (dictionary, YM Chat, comment box, etc) }\end{array}$ & - & - & - & 1 & 3 & 5 & 4.8 \\
\hline
\end{tabular}




\begin{tabular}{|c|c|c|c|c|c|c|c|c|}
\hline \multirow[t]{2}{*}{ No. } & \multirow[t]{2}{*}{ Statements } & \multicolumn{5}{|c|}{$\begin{array}{c}\text { Frequency of points } \\
\text { of agreement }\end{array}$} & \multicolumn{2}{|c|}{$\begin{array}{l}\text { Central } \\
\text { Tendency }\end{array}$} \\
\hline & & 1 & 2 & 3 & 4 & 5 & $\mathbf{N}$ & $\mathbf{M}$ \\
\hline 10. & $\begin{array}{l}\text { The Moodle Learning Model is easy to } \\
\text { navigate (provide clear instruction) }\end{array}$ & - & - & - & 1 & 4 & 5 & 4.6 \\
\hline 11. & $\begin{array}{l}\text { The Moodle Learning Model is free from } \\
\text { technical problem. }\end{array}$ & - & - & - & 2 & 3 & 5 & 4.6 \\
\hline 12. & $\begin{array}{l}\text { The Moodle Learning Model has a } \\
\text { consistency (colour, layout, font and } \\
\text { capitalization) are consistent from screen to } \\
\text { screen. }\end{array}$ & - & - & - & 1 & 4 & 5 & 4.8 \\
\hline 13. & $\begin{array}{l}\text { Generally, the learning model is well } \\
\text { designed }\end{array}$ & - & - & - & 3 & 2 & 5 & 4.4 \\
\hline \multicolumn{2}{|r|}{ ( } & - & - & 4 & 42 & 81 & & \\
\hline \multicolumn{2}{|c|}{ Total score } & \multicolumn{5}{|c|}{554} & \multirow{2}{*}{\multicolumn{2}{|c|}{ Good }} \\
\hline \multicolumn{2}{|c|}{ Mean } & \multicolumn{5}{|c|}{4,3} & & \\
\hline
\end{tabular}


